J. Perinat. Med. $11(1983) 272$

\title{
Pulmonary edema occurring after isoxsuprine and dexamethasone treatment for preterm labor: Case report
}

\author{
S. Evron, A. Samueloff, S. Mor-Yosef, E. Rosen, E. Sadovsky \\ Department of Obstetrics and Gynecology, Hadassah University Hospital, \\ Jerusalem, Israel
}

\section{Introduction}

Isoxsuprine, as other beta-adrenergic drugs, is a potent clinically used tocolytic agent $[4,13]$, increasingly used in the treatment of premature labor [8]. In the past, the major limiting factors in the use of isoxsuprine were its tendencies to produce tachycardia and hypotension.

Glucocorticoids are commonly used as an adjunct to beta-adrenergic drugs in the management of premature labor to accelerate fetal lung maturity [18].

Few reports in the American literature $[10,15,16$, 26], detail adverse maternal cardiovascular effects of beta-adrenergic drugs, especially when they are used in combination with glucocorticoids. The European literature reports several cases of cardiorespiratory complications related to the combined usage of betamimetic drugs and glucocorticoids $[9,12,24,27]$.

We have recently seen a potentially serious complication in a mother treated antenatally with isoxsuprine and dexamethasone. This was our first case of pulmonary edema seen during a period of five years usage of isoxsuprine.

\section{Case report}

A 28 year old woman, gravida 2, para 1, was admitted to the maternity ward with painful contractions in the 32 nd week of her second pregnancy. In her first pregnancy, she delivered prematurely in the $32 \mathrm{nd}$ week, a girl of $2300 \mathrm{~g}$.

\section{Curriculum vitae}

SHMUEL EVRON was born in Bagdad in 1945 and immigrated to Israel in 1950. In 19.70 he graduated from the Hebrew University Hadassah Medical School, Jerusalem and received the $M$. D. degree. During the years 19701974 he served in the Israel Defence Forces as a medical officer. Since 1974 he specialized in anesthesiology, including critical care medicine and subsequently specialized in obstetrics and gynecology at the Hadassah University Hospital and the Hebrew in Jerusalem. Special interest - hirsutism and fertility problems in hyperandrogenic women and experimental spidural analgesia in chronic catheterized animals.

The patient had no history of cardiac or pulmonary disease. Physical examination disclosed a thin woman. $48 \mathrm{~kg} \mathrm{~B}$. W. with no signs of cardiopulmonary disease. The uterine fundus measured was compatible with gestational age.

Therapy with intravenous isoxsuprine was begun with initial rate of $0.04 \mathrm{mg} / \mathrm{min}$ and increment of $0.04 \mathrm{mg} / \mathrm{min}$ every $15-30 \mathrm{~min}$ up to $0.32 \mathrm{mg} / \mathrm{min}$ (a total dose of $560 \mathrm{mg} / 48 \mathrm{hr}$ ). She was given two doses of intramuscular dexamethasone $12 \mathrm{mg}$ every 24 hours.

Forty-eight hours later, the patient experienced shortness of breath and chest pain. Examination disclosed wet rales over both lung fields; pulse rate was 120 beats $/ \mathrm{min}$, blood pressure $130 / 80 \mathrm{mmHg}$, respiration $34 \mathrm{breaths} / \mathrm{min}$, temperature $37^{\circ} \mathrm{C}$. An ECG showed sinus tachycardia. The hematocrit was $26 \%$ and electrolytes were normal except 
the serum potassium which was $3 \mathrm{mEq} /$ liter. Arterial blood gases on $0.5 \mathrm{FiO}_{2}$ face mask disclosed: $\mathrm{PO}_{2} 80$ torr $\mathrm{PCO}_{2} 28$ torr and $\mathrm{pH} 7.43$. There was a positive fluid balance of 1.7 liters in the first 24 hours and 5.2 liters in the next 24 hours. Treatment with iv $40 \mathrm{mg}$ furosemide, oxygen mask and $25 \mathrm{mg}$ meperidine was begun after discontinuation of isoxsuprine. She was placed in an erect position. Over the next four hours the clinical state improved greatly, the respiration declined to 20 breaths per minute, pulse rate to $90 / \mathrm{min}$ and urine output was three liters in $24 / \mathrm{h}$. However, examination of lung disclosed wet rales over the base of lung field and arterial blood gases on room air were $\mathrm{PO}_{2} 60$ torr, $\mathrm{PCO}_{2} 32$ torr. Eight hours from the start of dyspneic attack, the lung fields were clear and blood gases returned to the normal values. One day later, oral isoxsuprine $5 \mathrm{mg}$ every three hours were started. The patient tolerated therapy well, the uterine contractions were abolished and she was discharged on a regimen of oral isoxsuprine $80 \mathrm{mg}$ a day at the 34 weeks' gestation. She returned at the 38 weeks' gestation two days after stopping medication and delivered a $2860 \mathrm{~g}$ infant with APGAR scores of 9 and 10 at 1 and 5 minutes, respectively. The infant did well in the nursery. The patient has been followed up to six weeks. There was no clinical evidence of cardiovascular disease or renal impairment. The chest $x$-ray film and ECG were both normal.

\section{Discussion}

Preterm delivery affects approximately $6-10 \%$ of all births and is a leading cause of perinatal mortality [22]. The treatment of preterm labor with tocolytic agents has become widespread practice of obstetrics. However, maternal treatment with tocolytic agent is not necessarily harmless. Mild to severe side effects and complications have been sporadically reported with the use of tocolytic agents $[9,12,14,17,21,23,26,27,34]$. Their implications in pulmonary edema are summarized in Table I.

Isoxsuprine, although demonstrated to be of significant value in a randomized controlled study [8], has major limiting factors - a tendency to produce tachycardia and hypotension. However, these problems can be minimized if bolus administration is avoided [19]. In a retrospective study of 343 women [24] treated with isoxsuprine or terbutaline, the incidence of severe cardiovascular complications such as pulmonary edema and myocardial ischemia was higher among women treated with terbutaline than among those treated with isoxsuprine.

During the last five years, we have gained experience with the use of isoxsuprine in women for preterm labor. Our protocol today for the management of preterm labor, includes an initial intravenous administration of isoxsuprine and a following oral therapy $12-36$ hours later. The initial intravenous rate is $0.04 \mathrm{mg} / \mathrm{min}$ with an increment of $0.04 \mathrm{mg} / \mathrm{min}$ every $15-30 \mathrm{~min}$ up to $0.32 \mathrm{mg} / \mathrm{min}$ or a total dose of $280 \mathrm{mg} / 24 \mathrm{~h}$ followed by oral administration of $10 \mathrm{mg}$ every 1-3 hours.

These doses are much smaller than those reported previously [24] though potent enough for abolishing uterine contractions. Pulse rate is kept below 120 beats/min. Serum potassium is kept between $3.5-4 \mathrm{mEq} / \mathrm{L}$ and fluid intake is limited to 2-3 Liters/24 hours. Dexamethasone is administered when gestational weeks are 27-33 in two divided doses of $12 \mathrm{mg}$ every 24 hours. With such treatment regimen over a period of five years, only one out of 150 of our patients developed severe cardiovascular complications, i.e. pulmonary edema. The patient described here was young, with no prior cardiovascular disease. It seems that the generous fluid intake during the period of isoxsuprine and dexamethasone therapy contributed to the sudden episode of pulmonary edema.

The vulnerability of the pregnant patient treated with beta-adrenergic agents and glucocorticoid drugs to the sudden onset of cardiac embarrassment and pulmonary edema depends on the development of a compensated high cardiac output state during gestation. Isoxsuprine, as well as other beta-adrenergic agents increases the maternal pulse rate, causes peripheral vasodilatations and redistribution of the blood flow to several organs and increases the cardiac output $[6,7]$. Betaadrenergic agents may also have direct cardiotoxic effect [29] or may produce postcapillary pulmonary venoconstriction. Each of these effects can contribute to maternal heart failure. Corticoids with its mineralocorticoid activity of sodium and water retention, may bring about heart failure and pulmonary edema. Another factor that may place the pregnant patient at risk for cardiac failure with beta-adrenergic therapy, include anemia [20,25], pre-existing cardiac disease, hypokalemic and liberal use of crystalloid solutions [2, 16]. Anemia may lower peripheral vascular resistance by 


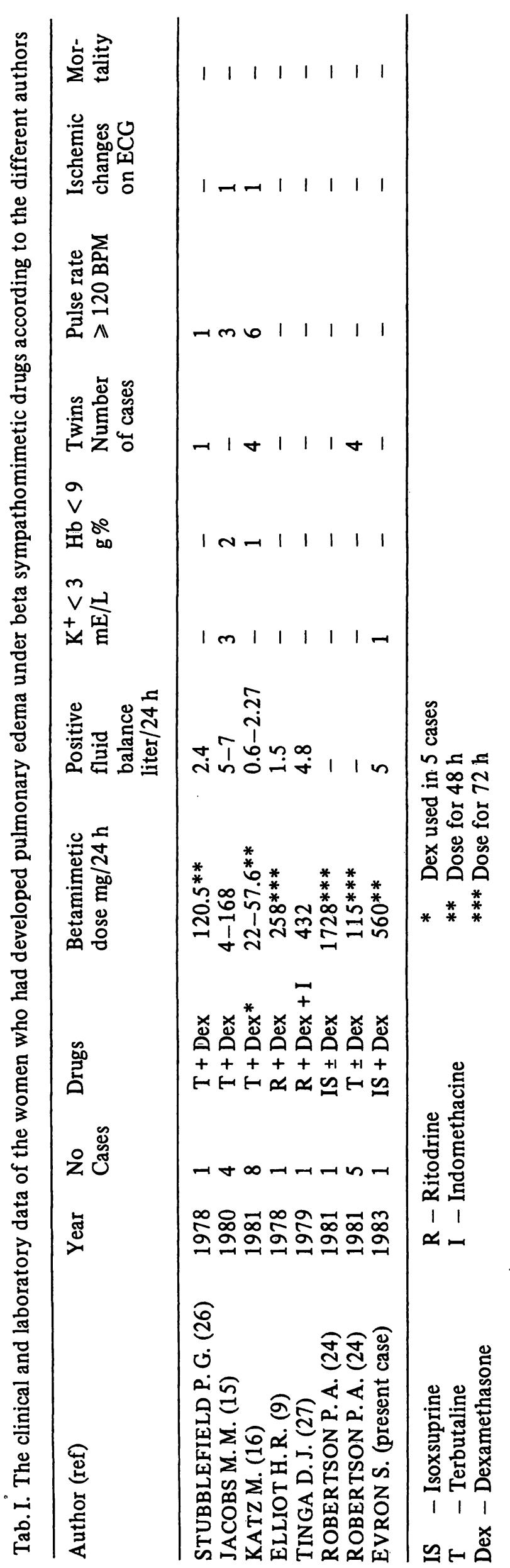


reducing blood viscosity, thus increasing cardiac output [20]. Hypokalemia may cause conduction and rhythm disturbances. In addition to the maternal problems, several neonatal complications have been reported after maternal treatment with beta-adrenergic agents. Most commonly recognized are hypoglycemia, hypotension, hypocalcemia and death $[1,5,11,28]$.

In the study of BENEDETTI [3] of two women with pulmonary edema using SWAN GANZ catheter, it was shown that except for high cardiac output, other cardiac indices such as mean arterial pressure, pulmonary artery pressure, pulmonary artery wedge pressures, colloid osmotic pressure and ejection fraction, were within the normal limits. It was suggested that a transient increase in pulmonary capillary permeability was the most likely etiology of pulmonary edema. However, the protein content in the edema fluid and the blood was not detected in that study. Despite the fact that pulmonary edema seen in the present and other reports $[9,10,15,16,24,26,27]$ was easily and quickly controlled, it is potentially dangerous. Therefore, further studies are necessary to elucidate the mechanism of pulmonary edema during the treatment with beta-adrenergic drugs. At the present time, it would seem prudent to include the following measure in the clinical management of patients receiving beta-adrenergic tocolytic therapy. Cardiovascular signs and symptoms should be monitored frequently, fluid balance and even fluid restriction should be accurately recorded and tachycardia greater than $120 \mathrm{bpm}$ for prolonged periods should be avoided.

Baseline blood samples for determination of hemoglobin, hematocrit and electrolytes are indicated especially in those patients having prolonged intravenous beta-adrenergic treatment. As soon as normal signs and symptoms are detected further studies should be carried out, including electrocardiography, arterial blood gases, and echocardiography.

\section{Summary}

A case of maternal pulmonary edema occurring in a patient in the 32 nd week of gestation is presented. This was our first case of pulmonary edema seen during a period of five years' usage of isoxsuprine in the treatment of premature labor. The patient presented was 28 years old, gravida 2, para 1, admitted to the maternity ward with premature uterine contractions. Her past history eliminate cardiac or pulmonary disease. Isoxsuprine therapy was begun with initial dose of $0.04 \mathrm{mg} / \mathrm{min}$. and increased to $0.32 \mathrm{mg} / \mathrm{min}$., the total dose administered was $560 \mathrm{mg}$ during 48 hours. During this period she was given in dexamethasone $24 \mathrm{mg}$. Fluid balance on the first day of the treatment was +1.7 liters and on the second day +5.2 liters. Forty-eight hours from the commencement of the treatment, the patient experienced shortness of breath and chest pain. Physical examination disclosed wet rales over both lungs, sinus tachycardia and tachypnea. Laboratory examination disclosed hypopotassemia of $3 \mathrm{mEq} /$ liter, hypoxemia $\left(\mathrm{PO}_{2}\right.$ of 80 torr on $0.5 \mathrm{FiO}_{2}$ face mask) with mild hyperventilation 28 torr $\mathrm{PCO}_{2}$ with normal ph 7.43.

Keywords: Isoxsuprine, preterm labor, pulmonary edema.

\section{Zusammenfassung}

Lungenödem nach Isoxsuprin- und Dexamethasontherapie bei vorzeitigen Wehen - Fallstudie

Wir berichten über eine Patientin, bei der in der 32. Schwangerschaftswoche ein Lungenödem auftrat.
Recognition of the early signs of pulmonary edema enable swift clinical diagnosis and steps to be taken to prevent disasterous condition due to progressive hypoxemia. The prompt treatment in this complication includes discontinuation of isoxsuprine and fluid administration, placement of the patient in an erect position, intravenous furosemid $40 \mathrm{mg}$, oxygen supplement by face mask and $25 \mathrm{mg}$ of meperidine. The patient's condition dramatically improved though the lung fields became completely clear from wet rales only eight hours from the start of dyspneic attack. A day later oral isoxsuprine was commenced in a dose of $5 \mathrm{mg}$ every three hours. This treatment was continued up to the 38th week of gestation when she delivered normally two days after discontinuation of the treatment. It is suggested that fluid overload was the event that triggered this complication, besides, it seems that our protocol for the treatment of premature labor seems safe. The ethiology of pulmonary edema in this case was discussed.
Nachdem wir über einen Zeitraum von 5 Jahren Isoxsuprin bei der Behandlung vorzeitiger Wehen eingesetzt haben, war dies der erste Fall, in dem wir ein Lungenödem beobachtet haben. Die 28jährige $Z$ weitgravida und 
Erstpara wurde mit vorzeitigen Wehen in unsere geburtshilfliche Abteilung überwiesen. Wir begannen die Isoxsuprintherapie mit einer Initialdosis von $0,04 \mathrm{mg} / \mathrm{min}$ und steigerten die Dosierung bis zu 0,32 mg/min. Die Gesamtdosis betrug $560 \mathrm{mg}$ über einen Zeitraum von 48 Stunden. Während dieser Zeit erhielt die Patientin zusätzlich $24 \mathrm{mg}$ Dexamethason i.m. Die Flüssigkeitsbilanz betrug am 1. Tag der Behandlung plus 1,71 und am 2. Tag plus 5,2 1. 48 Stunden nach Behandlungsbeginn klagte die Patientin über Kurzatmigkeit und Brustschmerzen. Bei der körperlichen Untersuchung hörte man feuchte Rasselgeräusche über beiden Lungen; außerdem bestand eine Sinustachykardie und eine Tachypnoe. Die Laborwerte zeigten eine Hypokaliämie von $3 \mathrm{mmol} / \mathrm{l}$, eine Hypoxämie $\left(\mathrm{P}_{2} 80\right.$ Torr unter Maskenbeatmung mit $\mathrm{O}_{2}, \mathrm{PCO}_{2}$ 28 Torr bei leichter Hyperventilation) und einen normalen $\mathrm{pH}$-Wert von 7,43 .

Dadurch, daß die Frühsymptome eines Lungenödems erkannt wurden, konnten wir die klinische Diagnose schnell sichern und Maßnahmen zur Verhinderung einer fortschreitenden Hypoxämie bzw. ihren verheerenden Folgen ergreifen. Isoxsupriniwurde sofort abgesetzt und jegliche Flüssigkeitszufuhr unterbunden; die Patientin wurde in eine sitzende Haltung gebracht und erhielt $40 \mathrm{mg}$ Furosemid i.v., $\mathrm{O}_{2}$ über eine Gesichtsmaske und $25 \mathrm{mg}$ Pethidin. Ihr Zustand besserte sich rasch, obwohl erst 8 Stunden nach Beginn der Dyspnoeanfälle keine feuchten Rasselgeräusche mehr über den Lungen zu hören waren. Einen Tag später verabreichten wir erneut $5 \mathrm{mg}$ Isoxsuprin oral alle 3 Stunden. Die Behandlung wurde bis zur 38. Schwangerschaftswoche fortgesetzt. 2 Tage nach Absetzen der Therapie kam es $\mathrm{zu}$ einer normalen Geburt. Wir glauben, daß eine $\mathrm{zu}$ große Volumenbelastung die Ursache für die beschriebenen Komplikationen war; unser Behandlungskonzept bei vorzeitigen Wehen erscheint uns weiterhin sicher. Darüber hinaus wird die Ätiologie des Lungenödems in dem beschriebenen Fall in der vorliegenden Arbeit diskutiert.

Schlüsselwörter: Isoxsuprin, Lungenödem, vorzeitige Wehen.

\section{Résumé}

Un cas d'oedème pulmonaire survenant après traitement d'isoxsuprine et de dexamethasone pour menace d'accouchement prématuré - une observation

Les auteurs rapportent une observation d'oedème pulmonaire maternel survenu à 32 semaines de gestation. Il s'agit de leur premier cas d'oedème pulmonaire sur une période, d'utilisation de l'isoxsuprine dans le traitement de l'accouchement prématuré, de cinq ans. Il s'agit d'une patiente de 28 ans, primipare, deuxième geste, hospitalisée dans la maternité de garde pour contractions utérines prématurées. A l'interrogatoire on élimine un antécédent d'affection cardiaque ou pulmonaire. L'isoxsuprine est débuté à la dose de $0,04 \mathrm{mg} / \mathrm{min}$, puis augmenté jusqu'à $0,32 \mathrm{mg} / \mathrm{min}$, la dose totale administrée a été de $560 \mathrm{mg}$ en 48 heures. En même temps, la patiente a reçu $24 \mathrm{mg}$ de dexamethasone en intramusculaire. La balance liquidienne du premier jour de traitement a été $\mathrm{de}+1,7$ litres et de $+5,2$ litres le deuxième jour. 48 heures après le début du traitement, la patiente ressent une gêne respiratoire et une douleur thoracique. A l'examen clinique on trouve des râles humides au niveau des 2 champs pulmonaires, une tachycardie sinusale et une tachypnée. Au niveau des examens complémentaires, on note une hypokaliémie à $3 \mathrm{mEq} /$ litre, une hypoxémie
( $\mathrm{PO}_{2}$ à 80 torr avec une $\mathrm{FiO}_{2}$ de 0,5 au masque) avec une hyperventilation modérée, $\mathrm{PCO}_{2}$ de 28 torr et un $\mathrm{pH}$ normal à 7,43 .

Grâce au dépistage des signes précoces d'oedème pulmonaire, le diagnostic clinique a été porté et des mesures prises pour éviter les complications secondaires à une hypoxémie progressive. Le traitement en urgence de cette complication comprend l'arrêt de l'isoxsuprine et du support liquidien, l'installation de la patiente en position verticale, l'injection intraveineuse de $40 \mathrm{mg}$ de furosémide, de l'oxygène au masque et $25 \mathrm{mg}$ de meperidine. L'état de la patiente s'améliore rapidement bien que les râles humides au niveau des champs pulmonaires ne disparurent totalement qu'au bout de 8 heures du début de la dyspnée. Un jour plus tard on commença un traitement par voie orale d'isoxsuprine à la dose de $5 \mathrm{mg}$ toutes les 3 heures. Ce traitement a été poursuivi jusqu'à la 38ème semaine de gestation, date à laquelle la patiente accoucha normalement 2 jours après l'arrêt du traitement. Les auteurs suggèrent que la surcharge liquidienne a été l'élément declencheur de cette complication; bien plus, ils estiment que leur protocole de traitement de l'accouchement prématuré n'est pas risqué. L'étiologie de l'oedème pulmonaire est discutée dans cette observation.

Mots-clés: Accouchement prématuré, isoxsuprine, oedème pulmonaire.

\section{Bibliography}

[1] BARDEN, T. P.: Inhibition of human premature labor by mesuprine hydrochloride. Obstet. and Gynec. 37 (1971) 98

[2] BENDER H. G., G. GOECHKENJAN, C. H. MEGER: Zum mütterlichen Risiko der medikamentösen Tokolyse mit Fenotorol. Geburtsh. Frauenheilk. 37 (1955) 665
[3] BENEDETTI, T.J., J. P. O'GRADY; J. C. HARGROVE, M. MORTON: Maternal pulmonary edema associated with terbutaline and betamethasone therapy: Hemodynamic observation presented at the meeting of the Society of Obstetric Anesthesia and Perinatology (SOAP). April 1-4, 1981, San Diego

[4] BiSHOP, E. H., T. B. WOUTERSZ: Arrest of premature labor. JAMA 178 (1961) 116 
[5] BRAZY, J. E., M. J. PUPKIN: Effects of maternal isoxsuprine administration on preterm infants. J. Pediat. 94 (1979) 444

[6] BURNELL R. H., G. W. MAXWELL: The cardiovascular effects of terbutaline. Eur. J. Pharmacol. 15 (1971) 383

i7] CARITIS, S. M., E. MUELLER-HENBACH, H. O. MORISHINAN: Effects of terbutaline on cardiovascular status and uterine blood flow in pregnant ewes. Obstet. and Gynec. 50 (1977) 603

[8] CSAPO, A. L., J. HERCZEG: Arrest of premature labor by isoxsuprine. Amer. J. Obstet. Gynec. 129 (1977) 482

[9] ElliOT, H. R., U. ABDULlA: Pulmonary edema associated with ritodrine infusion and betamethasone administration in premature labor. Brit. Med. J. 2 (1978) 799

[10] Elliot, J. P., D. R. O'KEEFE, P. GREENBERG: Pulmonary edema associated with magnesium sulfate and betamethasone administration. Amer. J. Obstet. Gynec. 134 (1979) 717

[11] EPSTEIN, M. F., E. NICHOLS, P. G. STUBbLEFIELD: Neonatal hypoglycemia after betasympathomimetic tocolytic therapy. J. Pediat. 94 (1979) 449

[12] ESKES, T., F. KUBLI: Discussion on beta-adrenergic agonists. Preterm labor. Edited by ANDERSON, A., R. BEARD, J. M. BRUNDENELL, Manchester, Richard Bates, 1977

[13] HENDRICKS, C. H., L. A. CibILS, S. V. POSE, T. K. A. B. ESKES: The pharmacologic control of excessive uterine activity with isoxsuprine. Amer. J. Obstet. Gynec. 82 (1961) 1064

[14] HOROWITZ, J., R. K. CREASY: Allergic dermatitis associated with administration of isoxsuprine. Amer. J. Obstet. Gynec. 131 (1978) 225

[15] JACOBS, M. M., A. B. KNIGHT, F. ARIAS: Maternal pulmonary edema resulting from beta mimetic and glucocorticoid therapy. Obstet. and Gynec. 56 (1980) 56

[16] KATZ, M., P. A. ROBERTSO, R. K. CREASY: Cardiovascular complications associated with terbutaline treatment for preterm labor. Amer.J. Obstet. Gynec. 139 (1980) 605

[17] KUBLI, F.: In preterm labour: Proceedings of the fifth study group of the Royal College of Obstetricians and Gynaecologists. Editors: ANDERSON, A, R. BEARD, J. M. BRUDENALL, P. M. DUNN, London, 1977

[18] LIGGINS, G. C., R. N. HowIE: A controlled trial of antepartum glucocorticoid treatment for the preven- tion of respiratory distress syndrome in premature infants. Pediatrics 50 (1972) 515

[19] LIPSHITZ, J., J. S. SCHNEIDER: Inhibition of labor. In SCIARRA, J. J., R. DEPP, D. A. ESCHENBACH (eds.): Gynecology and Obstetrics, Vol. 3, Maternal and Fetal Medicine Harper \& Row, Hagerstown, 1980

[20] MURRAY, J. F., E. ESCOBAR: Circulatory effects of blood viscosity. Comparison of methemoglobinemia and anemia. J. Appl. Physiol. 25 (1968) 594

[21] NAIR, G. V., A. K. GHOSH, B. V. LEWIS: Bowel distension during treatment of preterm labor with beta-receptor agonists. Lancet I (1977) 907

[22] BUTLER, N. R., D. G. BONHAM (eds.): Perinatal mortality, the first report of the British perinatal mortality survey. Livingstone, Edinburgh, 1963

[23] RIES, G. H.: Kasuistische Mitteilung über das Auf-

terbutaline. Tocolysis. Europ. J. Obstet. Gynec. heilk. 39 (1979) 33

[24] ROBERTSON, P.A., M. H. KATZ, R. K. CREASY: Maternal morbidity associated with isoxsuprine and terbutaline. Tcolysis. Europ. J. Obstet. Gynec. Reprod. Biol. 11 (1981) 371

[25] ROGGE, P., S. YOUNG, R. GOODLIN: Post partum pulmonary edema associated with preventive therapy for premature labor. Lancet II (1979) 1026

[26] STUBBLEFIELD, P. G.: Pulmonary edema occurring after therapy with dexamethasone and terbutaline for premature labor: A case report. Amer. J. Obstet. Gynec. 132 (1978) 341

[27] TINGA, D. J., J. G. AARONOUDSE, P. ROGGE: Postpartum pulmonary edema associated with preventive therapy for premature labor. Lancet I (1979) 1026

[28] UNBEHAUN, V.: Effects of sympathomimetic tocolytic agents on the fetus. J. Perinat. Med. 2 (1974) 2

[29] VAN VLIET, P. D., H. B. BURCHELL, J. L. TITUR: Focal myocarditis associated with pheochromocytoma. N. Engl. J. Med. 274 (1966) 1102

Received March 10, 1983. Revised April 30, 1983.

Accepted May 10, 1983.

Dr. S. Evron, Department of Obstetrics and Gynecology, Hadassah University Hospital Jerusalem, Israel 91120 